\title{
Effect of Klebsiella pneumoniae Enterotoxin on Intestinal Transport in the Rat
}

\author{
Frederick A. Klipstein, Ira R. Horowitz, Richard F. Engert, and \\ ERIC A. SCHENK \\ From the Tropical Malabsorption Unit of the Universities of Rochester and \\ Puerto Rico and the Isaac Gordon Laboratory for Gastrointestinal Research, \\ University of Rochester Medical Center, Rochester, New York 14642
}

A в STRACT The effects on intestinal transport of either a semipurified preparation of enterotoxin elaborated by Klebsiella pneumoniae or similarly prepared control material were tested by marker perfusion studies in the small intestine of rats. At a concentration of $2 \mathrm{mg} / \mathrm{ml}$, the enterotoxin produced net secretion of water, $\mathrm{Na}$, and $\mathrm{Cl}$ in both jejunal and ileal segments; $\mathrm{HCO}_{3}$ transport was not affected. Net secretion was evident within $30 \mathrm{~min}$ after introduction of the toxin and was maximal after $90 \mathrm{~min}$. The addition of $56 \mathrm{mM}$ glucose to the enterotoxin-containing perfusion fluid resulted in reversal of water and $\mathrm{Na}$ transport to net absorption in both intestinal segments. The enterotoxin also produced a significant depression of xylose absorption in both the jejunum and ileum but did not affect the absorption of either glucose or L-leucine. Intestinal structure was not altered after perfusion of the toxin but instillation of approximately one-quarter of the total perfusion dose into a ligated jejunal loop for $18 \mathrm{~h}$ produced fluid secretion and structural abnormalities. These observations confirm the fact that other species of coliform bacteria in addition to Escherichia coli are capable of elaborating an enterotoxin. Such species commonly contaminate the small intestine of persons with tropical sprue and it is suggested that chronic exposure of the intestinal mucosa to the enterotoxin elaborated by these bacteria may be a factor in the pathogenesis of intestinal abnormalities in this disorder.

\section{INTRODUCTION}

It is now well established that most persons with tropical sprue have colonization of their proximal small

This work was presented in part at the Annual Meeting of the American Gastroenterological Association, San Antonio, Tex., 20 May 1975. Gastroenterology. 68: 927, 1975 (Abstr.).

Received for publication $16 \mathrm{Inecomber} 1974$ and in resised form 2 June 1975. intestine by coliform bacteria (1-3). Among Puerto Ricans with untreated tropical sprue, these bacteria consist principally of Klebsiella pneumoniae and, less commonly, of Enterobacter cloacae or Escherichia coli (3). Concentrated preparations of crude cell-free broth filtrates of randomly selected strains of these bacteria have been shown to produce both fluid secretion and structural abnormalities in the rabbit ileal loop model $(3,4)$.

The enterotoxigenic material elaborated by $K$. pneumoniae is heat-stable and the results of fractionation procedures using sequential passage through varioussized ultrafiltration membranes indicate that its molecular weight is less than 10,000 (5). In the present study, we have used a marker perfusion technique in an experimental animal model to determine whether a semipurified preparation of Klebsiella enterotoxin induces net fluid and electrolyte secretion into the intestinal lumen, as do enterotoxins elaborated by a number of other enteric pathogens (6), and whether this flux can be reversed by the concomitant perfusion of glucose. We have also tested the effect of this enterotoxin on (a) the transport of several substances, including glucose, xylose, and L-leucine, whose absorption has been evaluated in persons with tropical sprue by the marker perfusion technique (7-9), and (b) intestinal structure in the rat.

\section{METHODS}

Preparation of Klebsiclla enterotoxin. A strain of $K$. pneumoniae serotype 5 , which was the predominant organism cultured from the midjejunal aspirate of a Puerto Rican with tropical sprue (3) and which we examined in previous studies (3-5), was used. The techniques employed in the preparation of the enterotoxin fraction have been reported (5). Briefly, cell-free broth filtrates were prepared by 18 -h stationary aerobic incubation in $250 \mathrm{ml}$ of trypticase soy broth in a 2 -liter flask after which the culture was centrifuged at $35,000 \mathrm{~g}$ at $4^{\circ} \mathrm{C}$ for $45 \mathrm{~min}$ and the 
supernate filtered through a $0.45-\mu \mathrm{m}$ Millipore filter adapted with a type AP 25 microfiber glass prefilter (Millipore Corp., Bedford, Mass.). 8 vol of acetone were added to the filtrate and the precipitate was allowed to settle for $18 \mathrm{~h}$ at $4^{\circ} \mathrm{C}$ after which the acetone was decanted and the precipitate dried by a stream of dry nitrogen and redissolved in distilled water to one-third of the original volume. The redissolved precipitate was centrifuged at $10,000 \mathrm{rpm}$ for $10 \mathrm{~min}$ to remove undissolved materials. The supernate was then passed with sequential filtration through Amicon UM 10 and UM 2 ultrafiltration membranes (Amicon Corp., Scientific Sys. Div., Lexington, Mass.) at $4^{\circ} \mathrm{C}$. The retentates of these membranes were taken to $10 \%$ of the original volume and then concentrated by lyophilization and stored at $-20^{\circ} \mathrm{C}$ until future use. The UM 2 retentate was used as the enterotoxin preparation in this study. $200 \mathrm{mg}$ of this material, reconstituted in $3 \mathrm{ml}$ of phosphate-buffered saline adjusted to yield an isotonic solution, consistently produces a positive response (fluid: length ratio greater than 1.0) in the rabbit ileal loop model whereas the UM 10 retentate is inactive at dosages of up to $500 \mathrm{mg}$ (5).

The control preparation consisted of the UM 2 retentate of trypticase soy broth without bacterial growth which was processed in a manner identical to that used in making the toxin.

Animal perfusion technique. Perfusion techniques were the same as those previously employed by other laboratories for the in vivo evaluation of intestinal transport by means of marker perfusion studies in rats $(10-12)$. Fasting Sprague-Dawley rats, weighing 250-300 g, were anesthetized with sodium pentobarbital, $90 \mathrm{mg} / \mathrm{kg}$ body wt given subcutaneously, tracheostomized, and kept in a constant temperature chamber which was maintained at $31^{\circ} \mathrm{C}$ throughout the perfusion procedure. Single $20-\mathrm{cm}$ intestinal segments were cannulated with polyvinyl tubing which started proximally at 4-6 $\mathrm{cm}$ from the stomach for jejunal segments and ended distally at $3-5 \mathrm{~cm}$ from the ileocecal valve for ileal segments. Only one segment was perfused in each rat; it was perfused at a rate of $0.5 \mathrm{ml}$ per min with a model 1201 Harvard peristaltic pump (Harvard Apparatus Co., Inc., Millis, Mass.) with the solution temperature adjusted to $37^{\circ} \mathrm{C}$ as it entered the animal by passage through a constant temperature bath. After a 30-min steady-state period, four 30 -min test fractions were collected by gravity drainage into covered, iced volumetric flasks and measured to the nearest $0.1 \mathrm{ml}$. The test preparation (control or toxin) was perfused during both the steady-state and test periods. At the termination of the experiment, the animals were exsanguinated by intracardiac puncture and the plasma osmolality and exact length of the segment perfused were determined. The plasma osmolality in 20 control rats was $317 \pm 3$ (mean $\pm \mathrm{SEM}$ mosmol/ $\mathrm{kg}$.

Composition of the perfusion fluid. The electrolyte solution described by Powell and Malawer (10) was used. This solution contains (in milliequivalents per liter) $\mathrm{Na} 150$, $\mathrm{K} 5, \mathrm{Cl} 125, \mathrm{CO}_{2} 30$, mannitol $16 \mathrm{mmol} / \mathrm{liter}$, and polyethylene glycol 4000 (PEG) ${ }^{1} 600 \mathrm{mg} / 100 \mathrm{ml}$ as a nonabsorbable water marker. This solution was modified in the present study by reducing the concentration of mannitol such that the osmolality of the perfusing fluid remained constant at $317 \mathrm{mosmol} / \mathrm{kg}$ when the following were added: xylose $2 \mathrm{mM}, \mathrm{L}-\left[1-{ }^{14} \mathrm{C}\right]$ leucine at a concentration of 10

${ }^{1}$ Abbreviations used in this paper: H\&E, hematoxylineosin; LT, heat-labile toxin; PEG, polyethylene glycol; ST, heat-stable toxin. $\mu \mathrm{Ci} /$ liter to which was added carrier leucine to make a total concentration of $2 \mathrm{mM}$, and $200 \mathrm{mg} / 100 \mathrm{ml}$ of either the toxin or control preparations. The $\mathrm{pH}$ of both the toxin and control solutions was 7.6.

In the glucose-containing solution, $\mathrm{Na}$ and $\mathrm{Cl}$ concentrations were reduced to 118 and $93 \mathrm{meq} /$ liter respectively, and glucose in a concentration of $56 \mathrm{mM}$ was added; the osmolality of this solution remained unchanged. Previous studies by Powell et al. have established that this combination of glucose and $\mathrm{Na}$ concentrations results in maximum water and $\mathrm{Na}$ absorption from the normal rat jejunum and ileum (13).

Chemical analysis. All chemical analyses were performed in duplicate. Na was measured by flame photometry. $\mathrm{HCO}_{3}$ values were determined immediately after each 30 min collection period by using an Oxford titrator (Oxford Laboratories, Foster City, Calif.) by Bittner and Hall's modification of the method of Van Slyke (14); this method involves back titration of an acidified sample with 0.005 $\mathrm{N}$ sodium hydroxide, with phenol red as an endpoint indicator. Chloride concentrations were determined with an Oxford titrator by the method of Schales and Schales (15), by titrating with acid mercuric nitrate in the presence of s-diphenylcarbazone as an endpoint indicator. Glucose levels were determined chemically by the $o$-toluidine method (16); the results were confirmed by duplicate determinations assayed by the glucose oxidase method using Glucostat enzyme reagents (Worthington Biochemical Corp., Freehold N. J.). Xylose concentrations were measured by the method of Roe and Rice (17). PEG was determined by a modification (18) of Hyden's turbidimetric technique (19). L-[1$\left.{ }^{14} \mathrm{C}\right]$ leucine was measured on a model 3380 Packard TriCarb liquid scintillation spectrometer (Packard Instrument Co., Inc., Downers Grove, II.), using Scintiverse scintillation mixture (Fisher Scientific Co., Pittsburgh, Pa.) with an efficiency of $78 \%$. Osmolalities were determined by measuring the freezing point depression with an Advanced DigiMatic osmometer (Advanced Instruments, Inc. Needham Heights, Mass.).

Net transport of water and solutes was calculated from changes in PEG and individual solute concentrations by the usual water marker technique equations (10). A transport value for each animal was derived by averaging the results of the four 30 -min test periods, and mean \pm SEM transport rates were calculated for the animals in each test group, which ranged from 5 to 7 in number. Net lumen-toblood transport is termed "absorption," which is signified by a plus sign, whereas a minus sign refers to net blood-tolumen transport, or secretion. The significance of difference in means was determined by Student's $t$ test for independent means.

At the termination of each study, Swiss rolls were made of the perfusion segment and of an adjacent nonperfused segment of intestine. One half of the Swiss roll was fixed in $10 \%$ buffered formalin and the sections stained with hemotoxylin-eosin ( $\mathrm{H} \& \mathrm{E})$ and with periodic-acid Schiff Alcian blue for goblet cell and brush border mucopolysaccharides; the other half was quick-frozen on dry ice and the sections stained with Oil Red $O$ for lipids and with the azo coupling method for acid and alkaline phosphatases (20).

\section{RESULTS}

\section{Control material}

The results of perfusing groups of rats with the control preparation in either the electrolyte or the glucose- 
TABLE I

Intestinal Transport of Water and Electrolytes in Animals Perfused with the Control Solution*

\begin{tabular}{|c|c|c|c|c|c|}
\hline Region & Glucose & $\mathrm{H}_{2} \mathrm{O}$ & $\mathrm{Na}$ & $\mathrm{Cl}$ & $\mathrm{HCO}_{3}$ \\
\hline Jejunum & No & $50.6 \pm 6.5$ & $8.0 \pm 1.1$ & $8.7 \pm 1.9$ & $5.9 \pm 1.9$ \\
\hline Jejunum & Yesł & $81.2 \pm 4.6$ & $11.1 \pm 2.6$ & $7.7 \pm 0.9$ & $9.5 \pm 1.5$ \\
\hline Ileum & No & $50.8 \pm 4.3$ & $9.8 \pm 1.2$ & $9.3 \pm 2.0$ & $-0.6 \pm 0.7$ \\
\hline Ileum & Yest & $69^{1} 0 \pm 3.0$ & $12.3 \pm 0.7$ & $9.6 \pm 1.6$ & $2.1 \pm 0.1$ \\
\hline
\end{tabular}

* Expressed in microliters (for water) or microequivalents (for electrolytes) per centimeter per $30 \mathrm{~min}$. Values are mean $\pm \mathrm{SEM}$ for all four test periods in groups of 5-7 rats. A negative sign indicates net secretion.

$\ddagger$ Presence or absence of glucose, $56 \mathrm{mM}$, in the perfusing fluid.

containing solution are shown in Table I. As has been noted by others $(12,21,22)$, under normal circumstances $\mathrm{HCO}_{3}$ is absorbed in the rat jejunum and secreted in the ileum. The addition of $56 \mathrm{mM}$ glucose to the perfusion fluid resulted in a significant enhancement of water $(P<0.02)$ and $\mathrm{Na}(P<0.05)$ absorption in the jejunum and of water $(P<0.01)$ absorption in the ileum.

\section{Enterotoxin}

Jejunum (Fig. 1). Perfusion of the toxin in the electrolyte solution resulted in secretion of water, $\mathrm{Na}$, and $\mathrm{Cl}$. The transport of $\mathrm{HCO}_{3}$ was unchanged.

Ileum (Fig. 2). The toxin produced net secretion of water, $\mathrm{Na}$, and $\mathrm{Cl}$, although the degree of secretion was less pronounced than that observed in the jejunum. Bicarbonate secretion was not affected.

Onset of toxin action (Fig. 3). With the $2 \mathrm{mg} / \mathrm{ml}$ dosage of toxin that was employed throughout this study, water secretion was evident in the jejunum during all four 30-min study periods and was maximum during period 3 at $90 \mathrm{~min}$ after initial exposure to the toxin. In the ileum, secretion was also present during

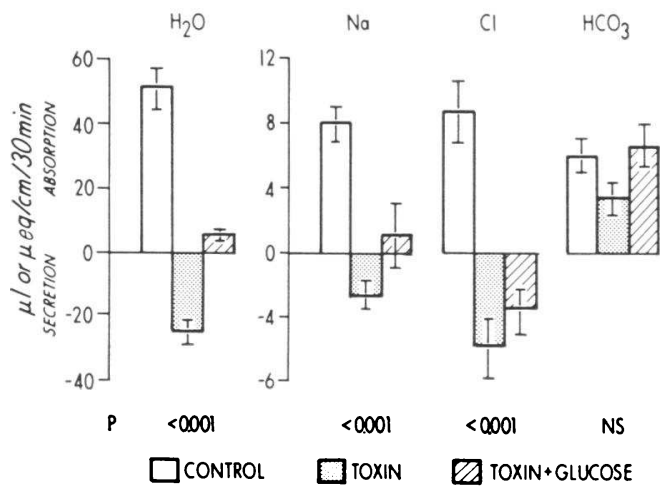

Figure 1 Effect of Klebsiella enterotoxin on water and electrolyte transport in the rat jejunum. The groups marked "control" and "toxin" were perfused in the electrolyte solution; the toxin plus glucose solution contained $56 \mathrm{mM}$ glucose. Values are mean $\pm S E M$ for all four test periods.

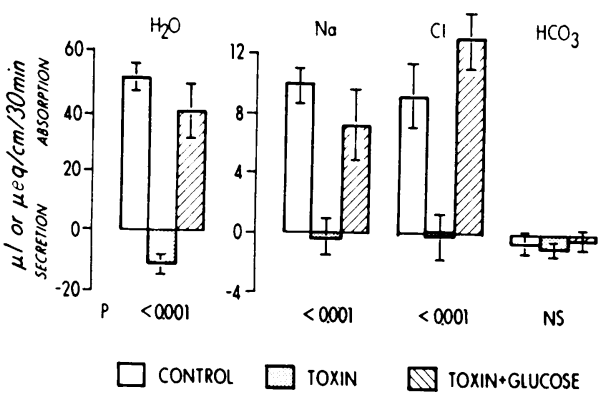

FIGURE 2 Effect of Klebsiella enterotoxin on water and electrolyte transport in the rat ileum. The groups marked "control" and "toxin" were perfused in the electrolyte solution; the toxin plus glucose solution contained $56 \mathrm{mM}$ glucose. Values are mean $\pm \mathrm{SEM}$ for all four test periods.

all four study periods and was maximum after exposure to the toxin for $60 \mathrm{~min}$. Four rats were perfused with the enterotoxin at a dosage of $1 \mathrm{mg} / \mathrm{ml}$. Secretion was present only during period 1 , after $30 \mathrm{~min}$ exposure to the toxin. Jejunal perfusion using a toxin dosage of $0.5 \mathrm{mg} / \mathrm{ml} \mathrm{did} \mathrm{not} \mathrm{affect} \mathrm{water} \mathrm{transport.}$

Effect of glucose. When the enterotoxin was perfused in a solution containing $56 \mathrm{mM}$ of glucose, water and $\mathrm{Na}$ transport were reversed from secretion to $\mathrm{ab}-$ sorption in the jejunum (Fig. 1), although the values for their absorption continued to be significantly less $(P<0.001$ for water, $<0.05$ for $\mathrm{Na})$ than those presin animals perfused with the control electrolyte solution. Secretion of $\mathrm{Cl}$ persisted and the absorption of $\mathrm{HCO}_{3}$ was not affected. In the ileum (Fig. 2), the addition of glucose to the toxin solution reversed water, $\mathrm{Na}$, and $\mathrm{Cl}$ transport from secretion to absorption values which were in the same range as those in animals perfused with the control electrolyte solution. The transport of $\mathrm{HCO}_{3}$ was not altered.

The degree by which glucose enhanced water and $\mathrm{Na}$ absorption appeared to be related to the magnitude of

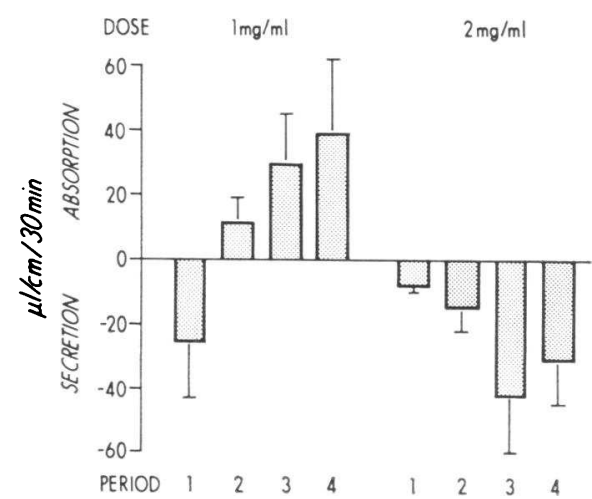

FIGURE 3 Onset of Klebsiella enterotoxin effect on water transport in the rat jejunum. Values are mean \pm SEM for each 30 -min period. 


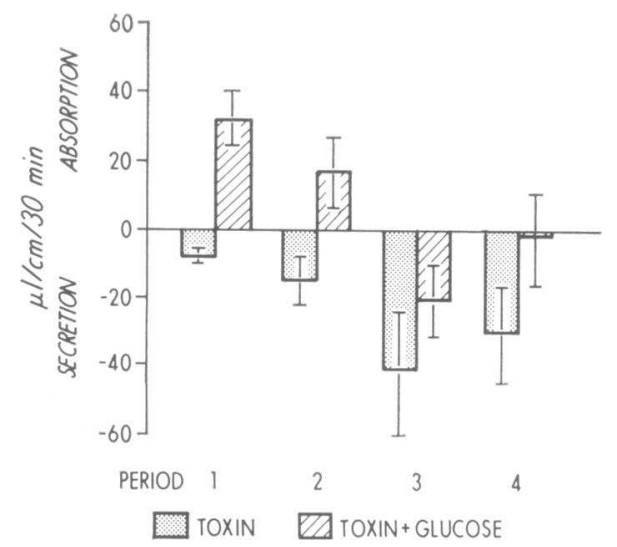

FIGURE 4 Effect of adding $56 \mathrm{mM}$ glucose to the perfusion fluid containing Klebsiella enterotoxin on water transport in the rat jejunum. Values are mean \pm SEM for each 30 -min period.

secretion induced by the enterotoxin. Thus, in the jejunum (Fig. 4), the addition of glucose resulted in water absorption during periods 1 and 2 but not during periods 3 and 4 during which time the enterotoxin produced the most striking secretion. Similarly, $\mathrm{Na}$ transport was reversed to absorption during periods 1 and 2 but remained in slight secretion during the last two periods; $\mathrm{Cl}$ transport remained in net secretion throughout all four periods, but secretion was less during the first two than during the last two periods. In the ileum, where the effect of the toxin in the electrolyte solution on water, $\mathrm{Na}$, and $\mathrm{Cl}$ transport was less striking than in the jejunum, the addition of glucose resulted in a more pronounced reversal to absorption.

Absorption of other test substances. The absorption of xylose was significantly less from the electrolyte solution containing toxin than from the control in both

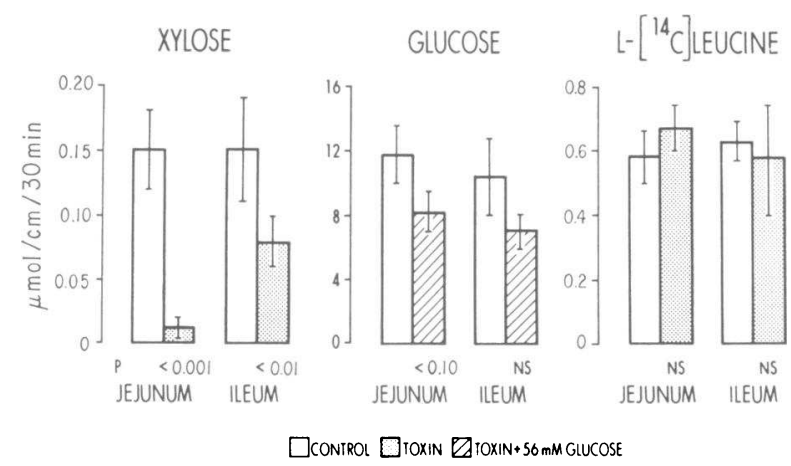

Figure 5 Effect of Klebsiella enterotoxin on intestinal absorption. Xylose and L-leucine absorption was measured from control and toxin preparations in electrolyte solution. Glucose absorption was measured from solutions containing $56 \mathrm{mM}$ glucose. Values are mean \pm SEM for all four test periods. the jejunum $(P<0.001)$ and ileum $(P<0.01)$ (Fig. $5)$. Values for xylose absorption from the glucosecontaining solution, which are not shown in the figure, were (in micromoles per centimeter per $30 \mathrm{~min}$ ) $0.38 \pm$ 0.08 (mean $\pm \mathrm{SEM}$ ) from the control and $0.08 \pm 0.02$ from the toxin preparation in the jejunum, and $0.10 \pm$ 0.01 from the control and $0.04 \pm 0.02$ from the toxin preparation in the ileum. Absorption from the toxin preparation was significantly $(P<0.001)$ reduced in the jejunum but not in the ileum.

The absorption of glucose was tested at two different concentrations. Absorption from the solution containing $56 \mathrm{mM}$ glucose with toxin (Fig. 5) was reduced below values in control animals in both the jejunum and ileum; however, the difference between absorption in the control and toxin groups was only marginally significant $(P<0.10)$ in the jejunum and not statistically significant in the ileum. Five additional rats were perfused with a solution containing $5.6 \mathrm{mM}$ glucose to which was added the control preparation during the first two 30 -min test periods and the toxin during the last three test periods (Fig. 6). The addition of the toxin resulted in reduced net water absorption, with net secretion during the last period, but no change was evident in glucose absorption as determined both by chemical analysis and by the transport of a tracer dose of $\mathrm{D}-\left[\mathrm{U}-{ }_{-}^{14} \mathrm{C}\right]$ glucose.

There was no difference between the transport of L-leucine in animals perfused with the control and toxin preparations (Fig. 5).

Intestinal structure. No morphologic abnormalities were observed in intestinal segments after perfusion

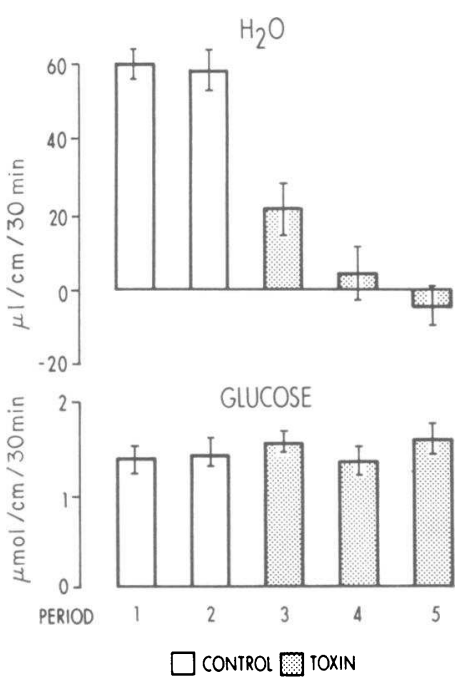

FIGURE 6 Effect of Klebsiella enterotoxin on water and glucose absorption from a solution containing $5.6 \mathrm{mM}$ glucose. The control preparation was perfused for the steady state and first two periods, the toxin for periods $3-5$. Values are mean \pm SEM for each 30 -min period. 


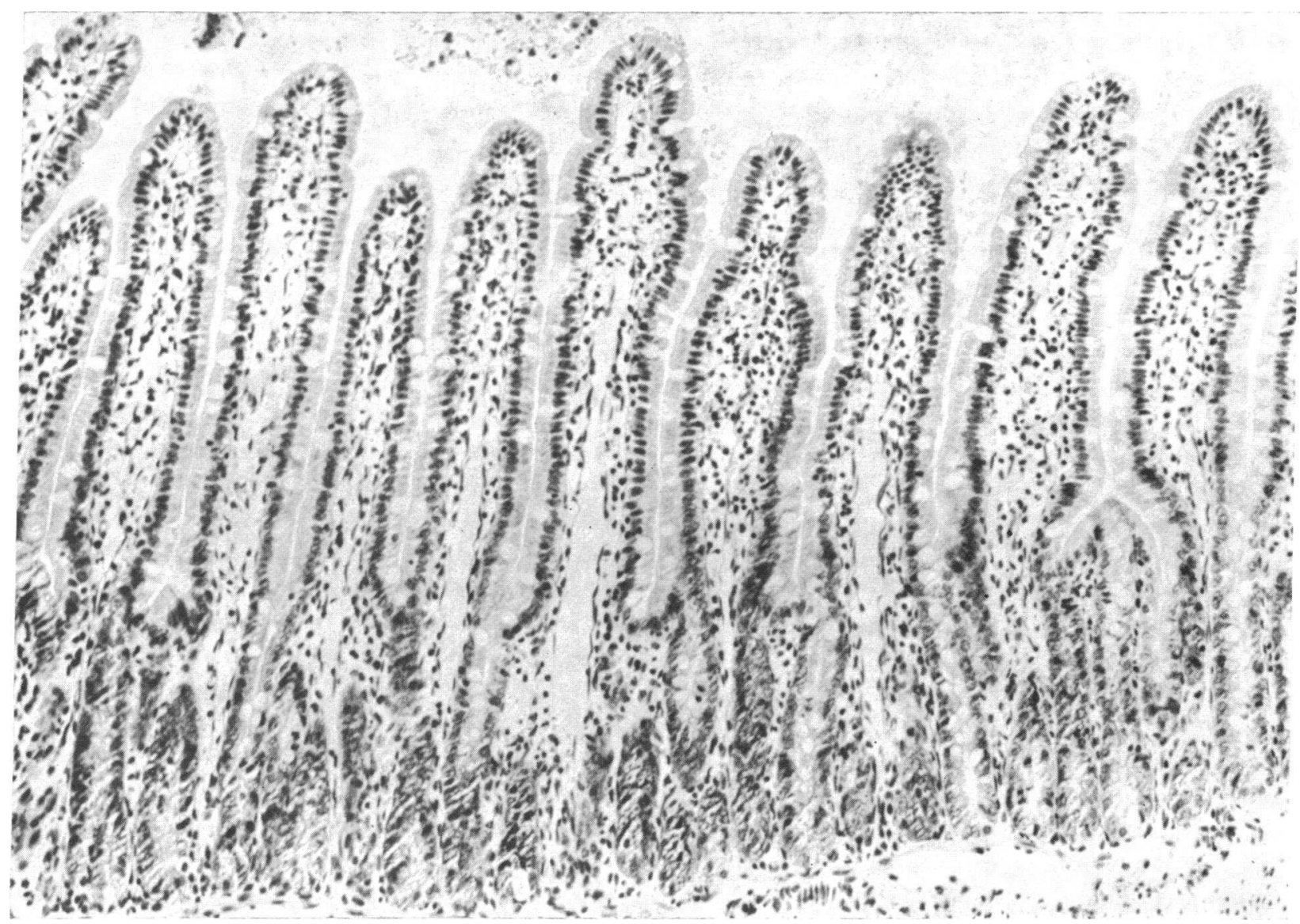

FIGURE 7 Jejunal segment exposed to a total dose of $150 \mathrm{mg}$ of Klebsiella toxin during perfusion for $2 \frac{1}{2} \mathrm{~h}$. Intestinal structure is normal. $\mathrm{H} \& \mathrm{E}, \times 80$.

with a total dose of $150 \mathrm{mg}$ of either the toxin or control preparation for a $2 \frac{1}{2}$-h period (Fig. 7). In 10 additional rats which were not perfused, two $10-\mathrm{cm}$ ligated jejunal loops were created. In five rats, $80 \mathrm{mg}$ of the toxin (in $1 \mathrm{ml}$ of phosphate-buffered saline) was placed in one loop and $80 \mathrm{mg}$ of the control material put in the adjacent loop; in the five other rats, the dosage of each material used was $40 \mathrm{mg}$. After $18 \mathrm{~h}$, the mean fluid: length ratio (milliliter: centimeter) was 0.39 in the loops containing $80 \mathrm{mg}$ of toxin, 0.35 in the loops containing $40 \mathrm{mg}$ of toxin, and 0.0 in the loops containing either dosage of the control material. A ratio of greater than 0.30 is considered indicative of a positive fluid response in the rat ligated loop (23). Jejunal loops containing either dosage of toxin showed both histologic and histochemical abnormalities (Fig. 8) similar to those which we have described in detail following the instillation of a crude cell-free broth filtrate of this strain of $K$. pneumoniae into the rabbit ileal loop model (4). No structural abnormalities were present in jejunal loops which contained the control material.

\section{DISCUSSION}

The effect of enterotoxins produced by five species of bacteria on the intestinal transport of water and electrolytes has been assessed by in vivo marker perfusion techniques in experimental animals to date. The most comprehensively studied, choleragen, a purified preparation of Vibrio cholerae enterotoxin, elicits net secretion of water and of $\mathrm{Na}, \mathrm{Cl}$, and $\mathrm{HCO}_{3}$ in both the proximal and distal small intestine of dogs (24-26) and rabbits (27-30). Toxigenic strains of E. coli elaborate either a heat-stable (ST) or heat-labile toxin (LT) or, in some instances, both types of toxin depending on the method of preparation $(31,32)$. Crude preparations of LT (33) or of partially (34-36) or completely (37) ST produce net secretion of water in the jejunum of dogs $(34,36)$, rabbits $(33,35)$, and calves (37). Partially ST has also been shown to increase the blood-tolumen flow of $\mathrm{Na}$ in the rabbit jejunum (35); and completely ST evokes net secretion of $\mathrm{Na}$ and $\mathrm{Cl}$ and enhances $\mathrm{HCO}_{3}$ secretion in the proximal and distal small intestine of calves (37). Shigella dysenteriae 1 enterotoxin evokes water secretion in the rabbit jejunum 


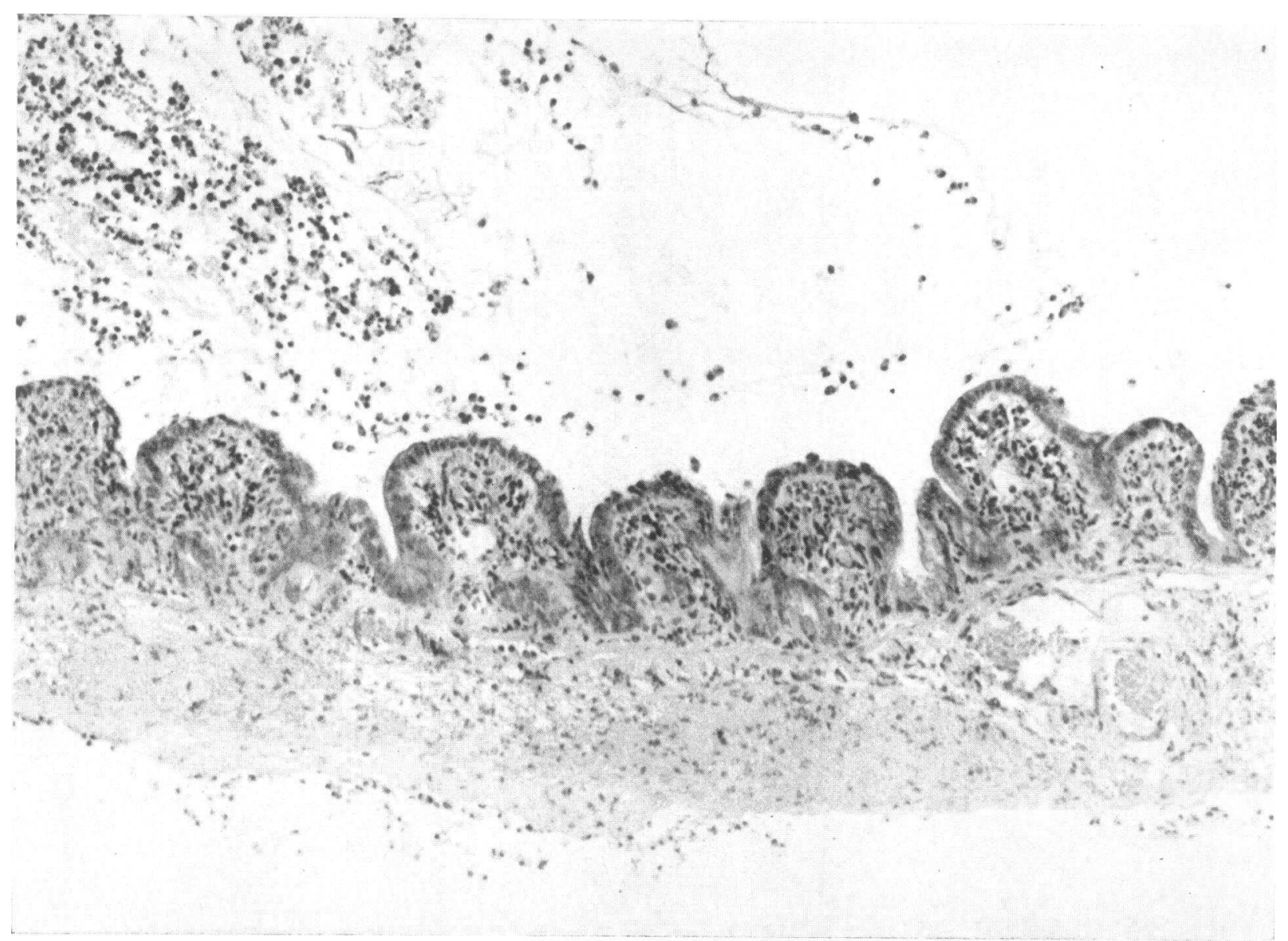

Figure 8 Ligated jejunal loop exposed to $40 \mathrm{mg}$ of Klebsiclla toxin for $18 \mathrm{~h}$. The villi have become shortened and broadened and there is submucosal venous congestion. H\&E, $\times 80$.

(30) ; enterotoxin B from Staphylococcus aureus produces transient secretion of water, $\mathrm{Na}, \mathrm{Cl}$, and $\mathrm{HCO}_{3}$ in the jejunum and ileum of rats (12); and Clostridium perfringens enterotoxin induces secretion of water, $\mathrm{Na}$, and $\mathrm{Cl}$ in the rat ileum (38).

The results of the present study indicate that Klebsiella enterotoxin also induces net secretion of water, $\mathrm{Na}$, and $\mathrm{Cl}$ into the proximal and distal small intestine of the rat. For reasons that are not clear to us, $\mathrm{HCO}_{3}$ transport was not affected by the toxin; it is possible that this may be a reflection of the animal model employed since disease of the rat ileum with Salmonella enteritis is associated with $\mathrm{HCO}_{3}$ absorption rather than enhancement of secretion (21), and $C$. perfringens enterotoxin does not induce $\mathrm{HCO}_{3}$ secretion when perfused through the rat ileum either (38). The minimum dose of Klebsiella enterotoxin found necessary to cause water secretion, $1,000 \mu \mathrm{g} / \mathrm{ml}$, is somewhat higher than that of preparations of various degrees of purity of other enterotoxins found effective in perfusion studies; these range from $2 \mu \mathrm{g} / \mathrm{ml}$ for staphylococcal enterotoxin B (12), $1 \mu \mathrm{g} / \mathrm{ml}$ for purified (34) and $12.5-25$ $\mu \mathrm{g} / \mathrm{ml}$ for NIH lot 001 cholera toxin $(30,35), 50 \mu \mathrm{g} / \mathrm{ml}$ for E. coli partially LT (34), and $63 \mu \mathrm{g} / \mathrm{ml}$ for partially ST (36) to $200 \mu \mathrm{g} / \mathrm{ml}$ for $S$. dysenteriae 1 toxin (30). The higher dosage found necessary for Klebsiella enterotoxin in the present study clearly relates to the fact that the material used was relatively impure. Subsequent purification procedures, employing Sephadex column chromatography, have yielded a fraction of this material that induces net water secretion in the rat jejunum at a dosage of $0.5 \mu \mathrm{g} / \mathrm{ml} .^{2}$

Klebsiella enterotoxin bears a number of resemblances to $E$. coli ST. Both are heat-stable and, in contrast to other enterotoxins (6), have a low molecular weight $(5,39)$, ST prepared by the same process and used in a similar dosage as in the present study evokes net water secretion in the ileum of calves (40). Whereas the effect of choleragen and $E$. coli LT on intestinal transport is not evident for several hours $(26,41)$, Klebsiella toxin and ST act promptly. Both evoke a de-

${ }^{2}$ Klipstein, F. A., and R. F. Engert. Unpublished observations. 
tectable fluid response in the rabbit ileal loop system within $2 \mathrm{~h}(4,41)$. During perfusion studies, net water secretion is evident within $30 \mathrm{~min}$ and maximum after 90 min exposure to ST (34-37) and we found such to be the case with Klebsiella toxin. In addition, submaximal dosages of either partially LT (34) or of Klebsiella toxin induce only transient net secretion of water whereas sustained secretion is achieved by the use of larger doses.

Under normal circumstances, glucose enhances the mucosal-to-serosal transport of sodium and water in the small intestine of humans (42) and experimental animals (43). This enhancement remains intact in experimental animals exposed to choleragen (24) or E. coli enterotoxins $(33,36,37)$, although Pierce and Wallace found that in the canine jejunum perfused with $E$. coli partially ST and glucose, water absorption did not return to levels present in the control animals (36). Perfusing Klebsiella enterotoxin, we found that glucose reverses water and $\mathrm{Na}$ transport from secretion to absorption in both the jejunum and ileum and that chloride transport was reversed in the ileum.

The effect of bacterial enterotoxins on the intestinal transport of substances other than water and electrolytes has not been extensively evaluated. The absorption of glucose was normal in various animal models which were perfused with choleragen with $26-65 \mathrm{mM}$ glucose $(24,44,45), E$. coli ST with $56 \mathrm{mM}$ glucose (37), and staphylococcal enterotoxin $\mathrm{B}$ with $20 \mathrm{mM}$ glucose (12). In contrast, glucose absorption was reduced when tested by Sherr et al., who perfused a $5.6 \mathrm{mM}$ solution of glucose plus E. coli partially ST (35), and $C$. perfringens enterotoxin was reported by $\mathrm{McDonel}$ to reduce glucose absorption from a $20 \mathrm{mM}$ solution (38). In the present study, glucose absorption was marginally reduced from a $56 \mathrm{mM}$ glucose solution containing Klebsiella enterotoxin and we wondered whether using a smaller, more physiologic concentration of $5.6 \mathrm{mM}$ might make an absorptive abnormality more apparent. Such did not prove to be the case. The absorption of glycine has been reported to be reduced in rabbits perfused with $E$. coli partially ST but not with choleragen (35); we observed no effect of Klebsiella enterotoxin on the absorption of leucine. The Klebsiella toxin did significantly reduce the absorption of xylose, both in the jejunum and ileum. Attention has recently been directed to the influence of water movement on the transport of solutes such as xylose and glucose (46); it is uncertain whether this factor contributed to the changes that we observed in xylose transport.

Contamination of the proximal small intestine with coliform bacteria is frequently present among persons in the tropics who have diarrhea associated with certain disorders. Such is the case among most malnourished children who have chronic diarrhea (47-51) and abnormalities of intestinal transport and structure $(52,53)$. Transient contamination by coliforms is also often present among children $(54,55)$ and adults $(56,57)$ in the tropics who have acute undifferentiated diarrhea. Strains of $K$. pneumoniae are commonly among the coliform bacteria isolated from children with diarrhea associated either with acute gastroenteritis or chronic malnutrition and this species was the most commonly encountered in two studies of such patients in Mexico $(47,54)$. Among 17 adults with acute undifferentiated diarrhea, many of whom were in a net fluid secretory state (58), who were evaluated by Gorbach, Banwell, and Chatterjee in Calcutta (57), 8 had a predominant flora of enterotoxigenic strains of $E$. coli within the jejunum and 9 had a mixed flora which, in 6 , included strains of $K$. pneumoniae. Coliform overgrowth within the jejunum is also well documented in persons with tropical sprue (1-3). In the single study in which the specific species of coliforms isolated from patients with this disorder were identified, $K$. pneumoniae was found to be either the predominant or only species present in 7 of 10 persons who had bacterial overgrowth (3). Previously, E. coli has been considered to be the only species of coliform bacteria capable of elaborating an enterotoxin. The results of previously reported observations from this laboratory (3-5) as well as those presently described indicate that other species of coliforms, including $K$. pneumoniae and E. cloacae, share this capacity.

It has been suggested that enterotoxigenic coliform bacteria may be a factor in the pathogenesis of the intestinal abnormalities present in tropical sprue (3). This suggestion is based on the observations that $(a)$ significant concentrations of these bacteria are commonly found present within the small intestine of patients with this disorder $(1-3)$; (b) the strains of these organisms tested are not invasive but elaborate an enterotoxin that produces structural abnormalities in the rabbit ileal loop model (4) that resemble those present in patients with tropical sprue $(59,60)$; and (c) the intestinal abnormalities in tropical sprue can be reversed to normal by therapy with either broadspectrum antibiotic agents $(61,62)$ or nonabsorbable sulfa preparations (63) which appear to act by reducing or erradicating the coliform bacteria (64). The results of the present study indicate that Klebsiella enterotoxin is also capable of inducing two of the abnormalities of intestinal transport that are commonly present early in the course of sprue, secretion of water and electrolytes and malabsorption of xylose (7). These abnormalities were observed under acute conditions in an experimental animal and their relationship to tropi- 
cal sprue in man in which the intestinal mucosa would be in contact with the enterotoxin for a longer periorl of time is uncertain. If the intestinal abnormalities in sprue are indeed related to exposure to toxin, it may well be that more chronic exposure is required to induce abnormalities such as malabsorption of glucose and amino acids which were not observed in the acute animal experiments but which are present in some patients with more advanced chronic sprue $(8,9)$. Supporting this concept would be the observations of O'Brien and England among British expatriates who acquire tropical sprue that during the first month after the onset of the disease, which often clinically resembles enterotoxin-induced tourista, derangements of intestinal morphology and absorption are usually mild and then become progressively more severe in the ensuing months (65).

\section{ACKNOWLEDGMENTS}

This investigation was supported by grants from the Williams-Waterman Fund of the Research Corporation, New York; The Hillsdale Fund, Greensboro, N. C.; and training grant 5-TO-1-AM-05177, National Institute of Arthritis, Metabolic and Digestive Diseases, Bethesda, Md.

\section{REFERENCES}

1. Gorbach, S. L., J. G. Banwell, B. Jacubs, B. D. Chatterjee, R. Mitra, N. N. Sen, and D. N. Guha Mazumder. 1970. Tropical sprue and malnutrition in West Bengal. I. Intestinal microflora and absorption. Am. J. Clin. Nutr. 23: 1545-1558.

2. Bhat, P., S. Shantakumari, D. Rajan, V. I. Mathan, C. R. Kapadia, C. Swarnabai, and S. J. Baker. 1972. Bacterial flora of the gastrointestinal tract in southern Indian control subjects and patients with tropical sprue. Gastroenterology. 62: 11-21.

3. Klipstein, F. A., L. V. Holdeman, J. J. Corcino, and W. E. C. Moore. 1973. Enterotoxigenic intestinal bacteria in tropical sprue. Ann. Intern. Med. 79: 632-641.

4. Klipstein, F. A., and E. A. Schenk. 1975. Enterotoxigenic intestinal bacteria in tropical sprue. II. Effect of the bacteria and their enterotoxins on intestinal structure. Gastroenterology. 68: 642-655.

5. Klipstein, F. A., and R. F. Engert. 1975. Enterotoxigenic intestinal bacteria in tropical sprue. III. Preliminary characterization of Klebsiclla pneumoniae enterotoxin. J. Infect. Dis. 132: 200-203.

6. Banwell, J. G., and H. Sherr. 1973. Effect of bacterial enterotoxins on the gastrointestinal tract. Gastroenterology. 65: 467-497.

7. Corcino, J. J., M. Maldonado, and F. A. Klipstein. 1973. Intestinal perfusion studies in tropical sprue. I. Transport of water, electrolytes, and d-xylose. Gastroenterology. 65 : 192-198.

8. Corcino, J. J., M. Maldonado, and F. A. Klipstein. 1972. Effect of glucose on jejunal transport of water and electrolytes in tropical sprue. Clin. Res. 20: 450. (Abstr.)

9. Klipstein, F. A., and J. J. Corcino. 1975. Malabsorption of essential amino acids in tropical sprue. Gastroenterology. 68: 239-244.
10. Powell, D. W., and S. J. Malawer. 1968. Relationship between water and solute transport from isosmotic solutions by rat intestine in vivo. Am. J. Physiol. 215: 4955.

11. Powell, D. W., G. R. Plotkin, R. M. Maenza, L. I. Solberg, D. H. Catlin, and S. B. Formal. 1971. Experimental diarrhea. I. Intestinal water and electrolyte transport in rat salmonella enterocolitis. Gastroenterology. 60 : 1053-1064.

12. Sullivan, R., and T. Asano. 1971. Effects of staphylococcal enterotoxin $\mathrm{B}$ on intestinal transport in the rat. Am. J. Physiol. 220 : 1793-1797.

13. Powell, D. W., G. B. Plotkin, L. I. Solberg, D. H. Catlin, R. M. Maenza, and S. B. Formal. 1971. Experimental diarrhea. II. Glucose-stimulated sodium and water transport in rat salmonella enterocolitis. Gastroenterology. 60: 1065-1075.

14. Bittner, D. L., and S. G. Hall. 1964. The titration of bicarbonate in plasma-critical factors. Am. J. Clin. Pathol. 42: 522. (Abstr.)

15. Schales, O., and S. S. Schales. 1941. A simple and accurate method for the determination of chloride in biological fluids. J. Biol. Chem. 140: 879-884.

16. Hyvärinen, A., and E. A. Nikkilä. 1962. Specific determination of blood glucose with $o$-toluidine. Clin. Chim. Acta. $7:$ : 140-143.

17. Roe, J. H., and E. W. Rice. 1948. A photometric method for the determination of free pentoses in animal tissues. J. Biol. Chem. 173 : 507-512.

18. Malawer, S. J., and D. W. Powell. 1967. An improved turbidometric analysis of polyethylene glycol utilizing an emulsifier. Gastroenterology. 53: 250-256.

19. Hyden, S. 1955. Turbidometric method for determination of higher polyethylene glycols in biologic materials. Ann. R. Agric. Coll. Swed. 22: 139-145.

20. Schenk, E. A., and F. A. Klipstein. 1972. Appendix to session II: a protocol for the evaluation of small bowel biopsies. Am. J. Clin. Nutr. 25: 1108-1117.

21. Powell, D. W., L. I. Solberg, G. R. Plotkin, D. H. Catlin, R. M. Maenza, and S. B. Formal. 1971. Experimental diarrhea. III. Bicarbonate transport in rat salmonella enterocolitis. Gastroenterology. 60: 10761086.

22. Hubel, K. A. 1969. Effect of luminal chloride concentration on bicarbonate secretion in rat ileum. $\mathrm{Am}$. J. Physiol. 217: 40-45.

23. Basu, S., and M. J. Pickett. 1969. Reaction of Vibrio cholerae and choleragenic toxin in ileal loop of laboratory animals. J. Bacteriol. 100: 1142-1143.

24. Carpenter, C. C. J., R. B. Sack, J. C. Feeley, and R. W. Steenberg. 1968. Site and characteristics of electrolyte loss and effect of intraluminal glucose in experimental canine cholera. J. Clin. Invest. 47: 1210-1220.

25. Moore, W. L., Jr., F. A. Bieberdorf, S. G. Morawski, R. A. Finkelstein, and J. S. Fordtran. 1971. Ion transport during cholera-induced ileal secretion in the dog. J. Clin. Invest. 50: 312-318.

26. Guerrant, R. L., L. C. Chen, and G. W. G. Sharp. 1972. Intestinal adenylcyclase activity in canine cholera: correlation with fluid accumulation. J. Infect. Dis. 125: 377-381.

27. Grayer, D. T., H. A. Serebro, F. L. Iber, and T. R. Hendrix. 1970. Effect of cycloheximide on unidirectional sodium fluxes in the jejunum after cholera exotoxin exposure. Gastroenterology. 58: 815-819.

28. Moritz, M., F. L. Iber, and E. W. Moore. 1971. Rabbit 
cholera: relation of transmural potentials to water and electrolyte fluxes. Am. J. Physiol. 221: 19-24.

29. Hubel, K. A. 1974. The mechanism of bicarbonate secretion in rabbit ileum exposed to choleragen. J. Clin. Invest. 53: 964-970.

30. Steinberg, S. E., J. G. Banwell, J. H. Yardley, G. T. Keusch, and T. R. Hendrix. 1975. Comparison of secretory and histological effects of shigella and cholera enterotoxins in rabbit jejunum. Gastroenterology. 68: 309-317.

31. Etkin, S., and S. L. Gorbach. 1971. Studies on enterotoxin from Escherichia coli associated with acute diarrhea in man. J. Lab. Clin. Med. 78: 81-87.

32. Gyles, C. L. 1971. Heat-labile and heat-stable forms of the enterotoxin from $E$. coli strains enteropathogenic for pigs. Ann. N. Y. Acad. Sci. 176: 314-322.

33. Whipp, S. C., and H. W. Moon. 1972. Modification of enterosorption induced by a heat-labile Escherichia coli enterotoxin in rabbit intestinal loops. Proc. Soc. Exp. Biol. Med. 140 : 395-398.

34. Guerrant, R. L., U. Ganguly, A. G. T. Casper, E. J. Moore, N. F. Pierce, and C. C. J. Carpenter. 1973. Effect of Escherichia coli on fluid transport across canine small bowell. Mechanism and time-course with enterotoxin and whole bacterial cells. J. Clin. Invest. 52: 1707-1714.

35. Sherr, H. P., J. G. Banwell, A. Rothfeld, and T. R. Hendrix. 1973. Pathophysiological response of rabbit jejunum to Escherichia coli enterotoxin. Gastroenterology. $65: 895-902$.

36. Pierce, N. F., and C. K. Wallace. 1972. Stimulation of jejunal secretion by a crude Escherichia coli enterotoxin. Gastroenterology. 63: 439-448.

37. Bywater, R. J. 1970. Some effects of Escherichia coli enterotoxin on net fluid, glucose and electrolyte transfer in calf small intestine. J. Comp. Pathol. 80: 565-573.

38. McDonel, J. L. 1974. In vivo effects of Clostridium perfringens enteropathogenic factors on the rat ileum. Infect. Immun. 10: 1156-1162.

39. Jacks, T. M., and B. J. Wu. 1974. Biochemical properties of Escherichia coli low-molecular-weight, heatstable enterotoxin. Infect. Immun. 9: 342-347.

40. Bywater, R. J. 1972. Dialysis and ultrafiltration of a heat-stable enterotoxin from Escherichia coli. J. Med. Microbiol. 5: 337-343.

41. Evans, D. G., D. J. Evans, Jr., and N. F. Pierce. 1973. Differences in the response of rabbit small intestine to heat-labile and heat-stable enterotoxins of Escherichia coli. Infect. Immun. 7: 873-880.

42. Fordtran, J. S., F. C. Rector, Jr., and N. W. Carter. 1968. The mechanisms of sodium absorption in the human small intestine. J. Clin. Invest. 47: 884-900.

43. Levison, R. A., and H. P. Sched1. 1968. Absorption of sodium, chloride and water and simple sugars in rat small intestine. Am. J. Physiol. 215: 49-55.

44. Iber, F. L., T. McGonagle, H. A. Serebro, E. Luebbers, T. M. Bayless, and T. R. Hendrix. 1969. Unidirectional sodium flux in small intestine in experimental canine cholera. Am. J. Med. Sci. 258: 340-350.

45. Serebro, H. A., T. M. Bayless, T. R. Hendrix, F. L. Iber, and T. McGonagle. 1968. Absorption of d-glucose by the rabbit jejunum during cholera toxin-induced diarrhoea. Nature (Lond.). 217: 1272-1273.

46. Ammon, H. V., P. J. Thomas, and S. F. Phillips. 1974. Influence of water movement on jejunal absorption in man. Clin. Res. 22: 634A.
47. Coello-Ramirez, P., and F. Lifshitz. 1972. Enteric microflora and carbohydrate intolerance in infants with diarrhea. Pediatrics. 49: 233-242.

48. James, W. P. T., B. S. Drasar, and C. Miller. 1972. Physiological mechanism and pathogenesis of weanling diarrhea. Am. J. Clin. Nutr. 25: 564-571.

49. Mata, L. J., F. Jiménez, M. Cordón, R. Rosales, E. Prera, R. E. Schneider, and F. Viteri. 1972. Gastrointestinal flora of children with protein-calorie malnutrition. Am. J. Clin. Nutr. 25: 1118-1126.

50. Gracey, M., M. Suharjono, M. D. Sunato, and D. E. Stone. 1973. Microbial contamination as another feature of malnutrition. Am. J. Clin. Nutr. 26: 1170-1174.

51. Heyworth, B., and J. Brown. 1975. Jejunal microflora in malnourished Gambian children. Arch. Dis. Child. 50: $27-33$.

52. Viteri, F. E., and R. E. Schneider. 1974. Gastrointestinal alterations in protein-calorie malnutrition. Med. Clin. North. Amer. 58: 1487-1505.

53. Schneider, R. E., and F. E. Viteri. 1972. Morphological aspects of duodenojejunal mucosa in protein-calorie malnourished children and during recovery. Am. J. Clin. Nutr. 25: 1092-1102.

54. Olarte, J., W. W. Ferguson, N. D. Henderson, and L. Torregrosa. 1961. Klebsiella strains isolated from diarrheal infants. Am. J. Dis. Child. 101: 763-770.

55. Chakraborty, P., and H. H. Shah. 1972. Bacterial aetiology of diarrhoea in infants and children. J. Indian Med. Assoc. 58: 200-204.

56. Rowe, B., J. Taylor, and K. A. Bettelheim. 1970. An investigation of travellers' diarrhoea. Lancet. 1: 1-5.

57. Gorbach, S. L., J. G. Banwell, B. D. Chatterjee, B. Jacobs, and R. B. Sack. 1971. Acute undifferentiated human diarrhea in the tropics. I. Alterations in intestinal microflora. J. Clin. Invest. 50: 881-889.

58. Banwell, J. G., S. L. Gorbach, N. F. Pierce, R. Mitra, and A. Mondal. 1971. Acute undifferentiated human diarrhea in the tropics. II. Alterations in intestinal fluid and electrolyte movements. J. Clin. Iniest. 50: 890-900.

59. Schenk, E. A., I. M. Samloff, and F. A. Klipstein. 1965. Morphologic characteristics of jejunal biopsy in celiac disease and tropical sprue. Am. J. Pathol. 47: 765-781.

60. Swanson, V. L., and R. W. Thomassen. 1965. Pathology of the jejunal mucosa in tropical sprue. Am. J. Pathol. 46: 511-551.

61. Guerra, R., M. S. Wheby, and T. M. Bayless. 1965. Long-term antibiotic therapy in tropical sprue. Ann. Intern. Med. 63: 619-634.

62. Rickles, F. R., F. A. Klipstein, J. Tomasini, J. J. Corcino, and N. Maldonado. 1972. Long-term follow-up of antibiotic-treated tropical sprue. Ann. Intern. Med. $76: 203-210$

63. Maldonado, N., E. Horta, R. Guerra, and E. PerezSantiago. 1969. Poorly absorbed sulfonamides in the treatment of tropical sprue. Gastroenterology. 57: 559568.

64. Gorbach, S. L., J. G. Banwell, R. Mitra, B. D. Chatterjee, B. Jacobs, and D. N. Guha Mazumder. 1969. Bacterial contamination of the upper small bowel in tropical sprue. Lancet. $1:$ 74-77.

65. O'Brien, W., and N. W. J. England. 1971. Tropical sprue amongst British servicemen and their families in South-East Asia. In Tropical Sprue and Megaloblastic Anaemia. Wellcome Trust Collaborative Study. Churchill Livingstone, London. 25-60. 